\title{
Ülkemiz Turnip Mosaic Virus Bamya İzolatının Tüm Genom Analizi
}

\author{
Gözde DEMİR ${ }^{1}, \quad$ Savaş KORKMAZ ${ }^{*}$
}

\section{öz}

Turnip mosaic virus (TuMV) dünyada konukçusu olduğu bitkilerin yetiştirildiği bölgelerde ekonomik düzeyde zarara neden olmaktadır. Dünyada son yıllarda yapılan bir çalışmada virüsün Brassicaceae familyasındaki bitkilerin dışında bamyayı da enfekte ettiği belirlenmiştir. Bu çalışma kapsamında bamyayı enfekte eden bir TuMV izolatının tüm genom dizi analizi yapılmıştır. Genom dizilimi belirlenen bamya TuMV izolatının diğer ülkelerdeki izolatlar ile karşılaştırılması sonucunda nükleotit düzeyinde \%77-93, amino asit düzeyinde ise \%89-97 oranında benzerliklere sahip olduğu bulunmuştur. Filogenetik analizler sonucunda ise bamya TuMV izolatının basal-B filogenetik grubunda yer aldığı görülmüştür. Bu çalışma ile ülkemizde ilk defa bamyayı enfekte eden bir TuMV izolatının genom düzeyinde moleküler karaktezasyonu gerçekleştirilmiştir.

Anahtar Kelimeler: RT-PCR, benzerlik, filogenetik

\section{The Complete Genome of Turkish Turnip Mosaic Virus Isolate Infecting Okra}

\begin{abstract}
Turnip mosaic virus (TuMV) causes economic damage to its hosts worldwide. In recent studies conducted in the world, it was determined that the TuMV infects okra besides the plants in Brassicaceae family. In this study, the complete genome sequence analysis of a TuMV isolate infecting okra was performed. The multiple sequence comparisons with world isolates showed that the okra isolate had $77-93 \%$ and $89-97 \%$ similarities at the nucleotide and amino acid levels, respectively. Moreover, it was found that the okra TuMV isolate was included in the basal-B phylogenetic group. With this study, the molecular characterization of a TuMV isolate infecting okra in Turkey was carried out for the first time at the complete genome level.
\end{abstract}

Keywords: RT-PCR, similarity, phylogenetic

ORCID ID (Yazar sirasına göre)

0000-0002-1377-4350, 0000-0001-8227-3800

Yayın Kuruluna Geliş Tarihi: 29.04.2021

Kabul Tarihi: 22.06.2021

${ }^{1}$ Çanakkale Onsekiz Mart Üniversitesi, Ziraat Fakültesi Bitki Koruma Bölümü, 17100 Çanakkale, Türkiye

E-posta: skorkmaz@comu.edu.tr 


\section{Ülkemiz Turnip Mosaic Virus Bamya İzolatının Tüm Genom Analizi}

\section{Giriş}

Ülkemizin bulunduğu özel coğrafi konumu, farklı iklimlerin görülmesi ve verimli geniş tarım arazilerine sahip olması nedeniyle çeşitli tarım ürünleri yetiştirilmektedir. Bu çeşitlilik sebze yetiştiriciliğinde de önemli bir yere sahiptir (Akbay ve ark., 2005). Ülkemizde sebze yetiştiriciliği gitgide artmakta olup, üretim son yıllarda neredeyse \%4 artarak yaklaşık 30 milyon tonu aşmıştır (TÜİK, 2019).

Bamya (Abelmoschus esculentus) pamuğunda içinde yer aldığı Ebegümecigiller (Malvaceae) ailesi içinde yer almasına rağmen pamuktan çok daha büyük sert yaprakları ve daha kalın bir gövdeye sahiptir (Lamont, 1999).

Bamya üretiminde zararlılar ve hastalıklar önemli sorunlar oluşturmaktadır (Asare-Bediako ve ark., 2014). Bamya üretimi, diğer sebze çeşitlerine kıyasla az zararlısı olmasına rağmen viral hastalıklar tarafindan tehdit altındadır (Lamont, 1999; Yadav ve ark., 2018). Kimyasal mücadelenin olmadığı viral hastalıklarda, fungal ve bakteriyel hastalıklara oranla kayıplar daha fazla olabilmektedir. Viral hastalıkların teşhisi, yayılma yollarının belirlenmesi, moleküler olarak karakterize edilmesi kontrol önlemlerinin planlanması açısından önemlidir (Provvidenti ve ark., 1996; Yasaka ve ark., 2017). Bu viral hastalıklardan en önemlisi şalgam mozaik virüsü (turnip mosaic virus; TuMV)'dür. TuMV, dünyada konukçusu olduğu bitkilerin üretiminin gerçekleştiği alanlarda ekonomik kayıplara sebep olabilmektedir (Ohshima ve ark., 2002).

Dünyada gerçekleştirilen çalışmalar sonucunda da birçok farklı konukçu ve ülkelerden TuMV enfeksiyonunun varlığ 1 bildirilmiştir (Zheng ve ark., 2017; Shevchenko ve ark., 2018). Ülkemizde de TuMV enfeksiyonu farklı konukçularda tespit edilmiştir (Gökdağ ve ark., 2016; Karanfil ve Korkmaz, 2016, 2020; Korkmaz ve Karanfil, 2017, Korkmaz ve ark., 2020). Ancak dünyada gerçekleştirilen çalışmalar sonucunda bamya bitkisinde TuMV varlığ $\breve{1}_{1}$ ilk kez 2001 yılında İsrail'den ve 2019 yılında da ülkemizden bildirilmiştir (Gera ve ark., 2001; Karanfil ve Korkmaz, 2019). Bitki virüs hastalıklarının genetik çeşitliliğinin belirlenmesinde çok önemli bir yer tutan tüm genom analizleri ise bamya bitkisinde şimdiye kadar gerçekleştirilmemiştir. Bu bağlamda bu çalışma kapsamında dünyada ilk kez bamyayı enfekte eden TuMV izolatının tüm genom dizilerinin belirlenerek genbankasında bulunan diğer izolatlar ile göstermiş olduğu filogenetik ilişkiler ve benzerlik sonuçları belirlenmiştir.

\section{Materyal ve Metot}

$\mathrm{Bu}$ çalışma temel olarak 3 aşamada gerçekleştirilmiştir. İlk aşamada Karanfil ve Korkmaz (2019)'n Manisa ve İzmir illerinden topladıkları TuMV ile enfekteli olduğu daha önceden tespit edilen bamya bitkileri içerisinden araștırmacıların sekanslama çalıșmalarına dahil etmedikleri toplam 6 izolat seçilmiştir. Seçilen bu izolatlarda total nükleik asit izalosyonu yapılarak, izolatların $\mathrm{NIb}+\mathrm{CP}$ (Nuclear Inclusion $\mathrm{b}+$ +Coat Protein) genleri RT-PCR yöntemi ile çoğaltılmış ve daha sonra sekanslanarak sahip oldukları gen dizilimleri çıkarılmıştır. İkinci aşamada dizilemesi yapılan izolatların diğer ülke izolatları ile göstermiş oldukları benzerlik ve filogenetik ilişkilerine göre aralarından bir izolat seçilmiştir. Çalışmanın son aşamasında ise seçilen bu izolatın tüm genom analizi için 5 farklı primer çifti ile bamya TuMV izolatının tüm genomu çoğaltılmış ve daha sonra sekanslanarak sahip olduğu gen dizimleri ortaya çıkarılmıştır. Elde edilen TuMV tüm genom dizilimleri kullanılarak bamya TuMV izolatının diğer ülkelerdeki TuMV izolatları ile göstermiş olduğu sekans benzerlikleri ve farklılıklarının yanında filogenetik ve evrimsel ilişkileri de ortaya konmuştur.

\section{Virüs İzolatı}

Çalışma kapsamında kullanılan bamya TuMV izolatları Karanfil ve Korkmaz (2019)'in Manisa ve İzmir illerinde bamya üretim alanlarından topladıkları TuMV ile enfekteli olduğu daha önceden tespit edilen izolatlar arasından tesadüfi olarak seçilmiştir.

\section{Total Nükleik Asit İzolasyonu}

TuMV ile enfekteli olduğu daha önceden bilinerek seçilen örnekten toplam nükleik asit 


\section{Ülkemiz Turnip Mosaic Virus Bamya İzolatının Tüm Genom Analizi}

(TNA) izolasyonu Li ve ark. (2008) ve Karanfil (2020)'nin önerileri doğrultusunda CTAB metodu ile 3 tekerrür olacak şekilde gerçekleştirilmiştir. Elde edilen TNA'ların kalitesi agaroz jel elektroforezi ile kontrol edildikten sonra, kullanilıncaya kadar $-80^{\circ} \mathrm{C}^{\prime}$ de saklanmıştır.

\section{Komplimentar DNA'ların Sentezlenmesi}

Bir RNA virüsü olan TuMV 3' ucunun sonunda poly A kuyruğuna sahiptir. $\mathrm{Bu}$ sebeple komplimentar DNA (cDNA)'lar random primer ile elde edilebileceği gibi, oligodT primerler yardımıyla da sentezlenebilmektedir. Bu çalışma kapsamında cDNA'ların eldesinde her iki primerde kullanılmıştır. $\mathrm{NIb}+\mathrm{CP}$ gen bölgesine göre gerçekleştirilen benzerlik ve filogenetik analizlerde random primer ile elde edilen cDNA'lar kullanılmıştır. Tüm genom analizleri için gerçekleştirilen PCR çalışmalarında ise 3' ucuna yakın bölgenin PCR ile çoğaltılmasında
oligodT ile elde edilen cDNA'lar kullanılırken, ara ve 5' ucuna yakın bölgeler için random primer ile elde edilen cDNA'lar kullanılmıştır. cDNA'ların sentezinde fermantas (Litvanya) firmasından sağlanan kitler kullanılmıştır.

\section{PCR Çalışmaları}

Gerçekleştirilen PCR çalışmaları NIb+CP gen bölgesi için Karanfil ve Korkmaz (2019)'un belirttiği PCR koşulları ve primer çifti kullanılarak, tüm genom analizleri için ise Shevchenko ve ark. (2018)'nın belirttiği PCR koşulları ve 5 farklı primer çifti kullanılarak gerçekleştirilmiştir (Çizelge 1). Tüm genom analizlerinde kullanılan TuMV izolatı $\mathrm{NIb}+\mathrm{CP}$ gen dizilimleri göre gerçekleştirilen benzerlik ve filogenetik analiz sonuçlarına göre seçilmiştir. PCR reaksiyonlarında Takara (Japonya) firmasından sağlanan PCR mastermiks kullanılarak ve MJ Mini (Bio-Rad, ABD) PCR cihazında gerçekleştirilmiştir.

Çizelge 1. PCR çalışmalarında kullanılan primer çiftleri

\begin{tabular}{|c|c|c|}
\hline Primer kodu & Sekans (5'-3') & Ürün büyüklüğü (bç) \\
\hline \multicolumn{3}{|c|}{$\mathrm{NIb}+\mathrm{CP}$ gen bölgesi primer için primer çifti } \\
\hline TUNIP17P & TGG TTY ATG TCG CAC CAA GG & \multirow[t]{2}{*}{1178} \\
\hline CP8M & TCC GTG TTC TCT ACC GTT GT & \\
\hline \multicolumn{3}{|c|}{ Tüm genom dizilimlerinin belirlenmesi için primer çiftleri } \\
\hline Tu5T4P & AAAAATATAAAAACTCAACATAACAT & \multirow[b]{2}{*}{3230} \\
\hline TuP3OP1M & CGCTGTATCTGCCGCCTAAATC & \\
\hline TuKA1HC11P & TTCATATGGGGTGAGAGAGG & \multirow[b]{2}{*}{1898} \\
\hline Tu596K17M & TCTGCGTCAAACATCATGAG & \\
\hline TuP3OP1P & CARAT CTTGGACGAAGCATGGA & \multirow[b]{2}{*}{3008} \\
\hline TuVPG8M & TCAA ATCCATACATGTTGATGAA & \\
\hline Tu59CI9P & GTGCTTGARGGAGCRAAGTC & \multirow[b]{2}{*}{1691} \\
\hline TuNI B14M & ACYGTGTGCTTYGTCACAAG & \\
\hline Tu59NIA3P & GCAARCTAATMTCAGACCTYG & \multirow[b]{2}{*}{2621} \\
\hline Tu3T9M & GGGG CGGCCGCT15 & \\
\hline
\end{tabular}

\section{Sekanslama ve Biyoinformatik Analizler}

TuMV izolatlarının $\mathrm{NIb}+\mathrm{CP}$ gen dizilimleri çift yönlü olarak sanger sekanslama metodu ile BM Labosis firmasından hizmet alımı alınarak gerçekleştirilmiştir. Seçilen TuMV izolatının tüm genom dizilimine ait veriler ise yeni nesil dizileme (NGS) metodu temelli olarak amplikon dizileme hizmeti ile FicusBio firmasından hizmet alımı alınarak gerçekleştirilmiştir. Biyoinformatik analizlerde CLC Main
Workbench, CLC Genomic bench, MEGAX ve SDT programlarından yararlanılmıştır (Muhire ve ark., 2014). Ayrıca bu çalışmalarda kullanılan diğer ülkelerdeki TuMV izolatlarına ait veriler Çizelge 2'de verilmiştir. Seçilen izolatların diğer ülkelerdeki TuMV izolatları ile göstermiş oldukları benzerlik oranları nükleotit ve amino asit düzeyinde yüzde olarak belirlenmiştir. Ayrica filogenetik analizler ile de bamya TuMV izolatının ait olduğu grup belirlenmiştir. 


\section{Ülkemiz Turnip Mosaic Virus Bamya İzolatının Tüm Genom Analizi}

Çizelge 2. Benzerlik ve filogenetik analizlerde kullanılan diğer ülkelerdeki turnip mosaic virus izolatlarının isimleri ve erişim numaraları

\begin{tabular}{|c|c|c|c|c|c|}
\hline İzolat & $\begin{array}{l}\text { Erişim } \\
\text { Numaras1 }\end{array}$ & İzolat & $\begin{array}{l}\text { Erişim } \\
\text { Numaras1 }\end{array}$ & İzolat & $\begin{array}{l}\text { Erişim } \\
\text { Numaras1 }\end{array}$ \\
\hline GRC42 & AB252117 & OMA & AB701691 & IRNTOFS3 & AP017800 \\
\hline GRC43 & AP017756 & $\mathrm{OM}$ & AB701690 & IRNCV1 & AP017752 \\
\hline GRC39 & AP017840 & ORM & AB701692 & IRNTuSh18 & AP017808 \\
\hline ITA1A & AB701720 & OS & AB701693 & IRNS1 & AP017788 \\
\hline ITA8 & AB189014 & DEU4 & AB701701 & IRNRN6 & AP017785 \\
\hline Cal1 & AB093601 & HRD & AB093627 & IRNRaNi3 & AP017780 \\
\hline ITA2 & AB701721 & CH6 & AB179888 & IRNKhCa & AP017770 \\
\hline TUR242 & AP017815 & BJ-B01 & KC119185 & KWB779J & AB252125 \\
\hline TUR10 & AP017864 & IRNTKE & AP017797 & AUST21 & AB989637 \\
\hline TUR9 & AB362513 & IRNRkaraj & AP017784 & VIET58 & AB747288 \\
\hline TUR77 & AP017884 & IRNMB6 & AP017773 & VIET80 & AB747293 \\
\hline TUR20 & AP017867 & IRNTOFS6 & AP017801 & CZE5 & AB188916 \\
\hline BZ1 & AB093611 & RUS1 & AB093606 & DNK3 & AB701703 \\
\hline CAR37A & DQ648591 & CAR51 & HQ637383 & & \\
\hline
\end{tabular}

\section{Sonuçlar ve Tartışma}

Çalışma kapsamında total nükleik asit izolasyonu başarılı bir şekilde gerçekleştirilmiştir. NIb+CP genlerinin RT-PCR analizleri için TuMV ile enfekteli olduğu bilinen 6 örnek üzerinden çalışmalar yürütülmüş ve 6 izolatın $\mathrm{NIb}+\mathrm{CP}$ gen bölgeleri spesifik primer

çiftleri ile çoğaltılmıştır. TuMV NIb+CP genine karşıllk gelen 1178 bç büyüklüğünde bant oluşumu seçilen tüm örneklerde gözlenmiştir. Su örneği ve negatif kontrolde ise herhangi bir bant oluşumu gözlenmemiştir (Şekil 1).

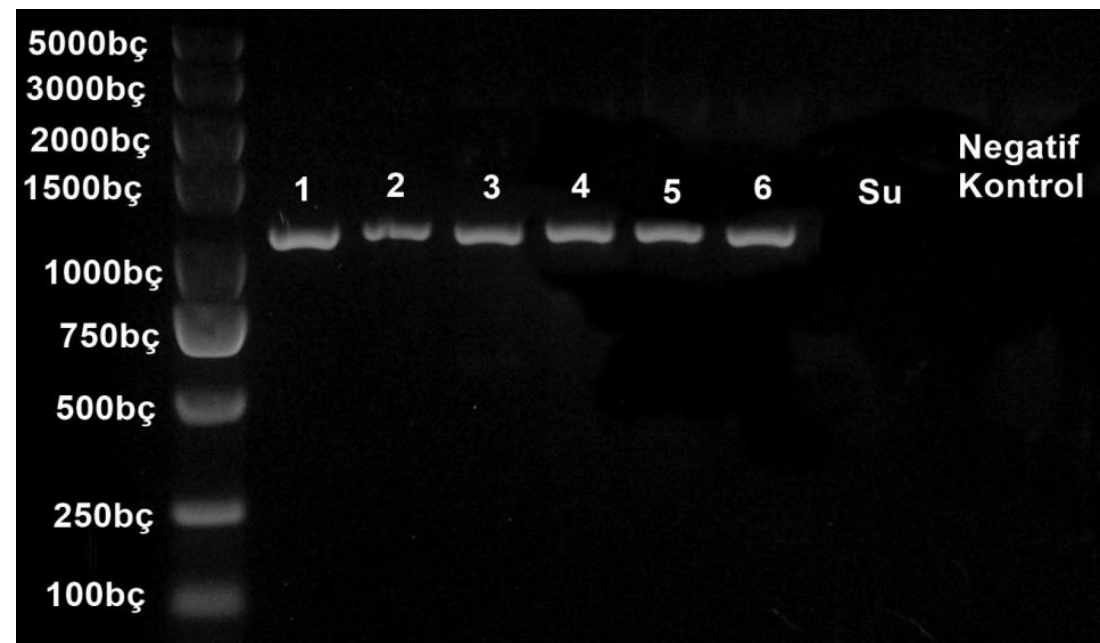

Şekil 1. RT-PCR ürünlerinin agaroz jel elektroforezinde kontrol edilmesi sonucunda oluşan bant görüntüleri (M:100-5000 bç marker; 1, 2, 3, 4, 5, 6: Turnip mosaic virus ile enfekteli izolatlara ait numaralar) 


\section{Ülkemiz Turnip Mosaic Virus Bamya İzolatının Tüm Genom Analizi}

$\mathrm{NIb}+\mathrm{CP}$ gen bölgeleri PCR yöntemi ile çoğaltılan 6 izolat içerisinden seçilen üç izolatın DNA dizilimleri her iki yönden olacak şekilde belirlenmiştir. DNA dizileri elde edilen TuMV izolatlarının (1: CNKOkraa, 2: CNKOkrab ve 3: CNKOkrac) nükleotit ve amino asit dizileri kendi içlerinde ve diğer ülkelerdeki TuMV izolatları ile benzerlik ve filogenetik açidan karşılaştırılarak tüm genom dizisi belirlenecek bir adet TuMV izolatının seçimi yapılmıştır.

TuMV bamya izolatının nükleotit ve amino asit temelli kendi içlerinde ve diğer ülkelerdeki TuMV izolatları ile gösterdiği benzerlik oranları gerçekleştirilen çoklu dizi analizleri sonucunda belirlenmiştir.

CNKOkraa, CNKOkrab ve CNKOkrac TuMV izolatlarının nükleotit ve amino asit temelli kendi içlerinde sırasıyla \%98 ve \%99'un üzerinde benzerlik gösterdikleri belirlenmiştir.

Karanfil ve Korkmaz (2016), yaptıkları çalışmada CKO1 Türk izolatının nükleik asit dizilimlerine göre gen bankasındaki diğer TuMV izolatları ile karşılaştırmışlardır. Karşılaştırmaları sonucunda CKO1 izolatının nükleotit seviyesinde \%88-93 benzerlik aralığına sahip olduğunu ortaya çıkarmışlardır. Korkmaz ve ark. (2020), tarafindan ülkemizde gerçekleştirilen başka bir çalışmada ise, Türk TuMV izolatlarının $\mathrm{NIb}+\mathrm{CP}$ geninin nükleotit ve amino asit bazlı çoklu dizi karşılaştırması sonucunda Türk TuMV izolatların diğer ülkelerdeki TuMV izolatları ile \%83-100 nükleotit ve \%90-100 arasında amino asit seviyesinde benzerlik gösterdiğini bildirmişlerdir. $\mathrm{Bu}$ çalıșmada elde ettiğimiz sonuçlarla daha önceden yapılan çalışmalarda elde edilen sonuçlar birbirini destekler nitelikte olduğu görünmektedir.

TuMV izolatlarının filogenetik soy ağacının saptanması için gerçekleştirilen çalışmalar sonucunda CNKOkraa, CNKOkrab ve CNKOkrac izolatlarının diğer ülkelerdeki TuMV izolatları ile genetik ilişkilerinin belirlenmesi amacıyla $\mathrm{NIb}+\mathrm{CP}$ geninin nükleotit düzeyinde filogenetik ilişkileri araştırılmıştır.
Gerçekleştirilen filogenetik analizler sonucunda CNKOkraa, CNKOkrab ve CNKOkrac TuMV izolatlarının hepsinin basal-B grubuna dahil olduğu bulunmuştur. Karanfil ve Korkmaz (2016), ülkemizde ilk kez bamyada TuMV enfeksiyonunu bildirdikleri çalışmalarında da TuMV izolatlarının basal-B filogenetik grubuna ait olduklarını bildirmişlerdir.

Çalışma kapsamında gerçekleştirilen ilk aşama olan $\mathrm{CP}+\mathrm{NIb}$ genine göre yapılan benzerlik çalışmaları CNKOkraa, CNKOkrab ve CNKOkrac izolatları üzerinden yürütülerek sonlandırılmıştır. İkinci aşama için bu 3 izolat birbirleri ile \%99'un üzerinde bir benzerlik gösterdikleri için bundan sonraki benzerlik ve filogenetik çalışmaları için CNKOkrab izolatı seçilerek CNKOkra olarak isimlendirilmiştir. Tüm çalışmalar CNKOkra üzerinden yürütülmüştür.

Tüm genom çalışmaları kapsamında seçilen bir adet TuMV izolatına yapılan RT-PCR çalışması sonuçlarında istenilen bant büyüklüklerinin elde edildiği görülmüştür. Tu5T4P ve TuP3OP1M için 3230 bç uzunluğunda, TuKA1HC11P ve Tu596K17M için 1898 bç uzunluğunda, TuP3OP1P ve TuVPG8M için 3008 bç uzunluğunda, Tu59CI9P ve TuNI B14M için 1691 bç uzunluğunda ve Tu59NIA3P ve Tu3T9M için 2621 bç uzunluğunda TuMV tüm genomuna ait istenilen bant uzunlukları elde edilmiştir (Şekil 2).

Çalışma kapsamında seçilen CNKOkra izolatının diğer ülkelerdeki TuMV izolatları ile benzerlik ilişkileri araştırıldığında, nükleotit temelli gerçekleştirilen benzerlik analizi sonucuna göre tüm izolatlar dikkate alındığında \%77-93 arasında benzerlik gösterdiği belirlenmiştir. CNKOkra izolatı TUR242 isimli ve AP017815 erişim numaralı Türkiye izolatı ile \%93 oranında en yüksek benzerliği gösterirken, en düşük benzerliği ise $\% 77$ oranında OMA, OM, ORM ve OS isimli AB701691, AB701690, AB701692 ve AB701693 erişim numaralı Almanya izolatları ile gösterdiği belirlenmiştir (Şekil 3). 


\section{Ülkemiz Turnip Mosaic Virus Bamya İzolatının Tüm Genom Analizi}

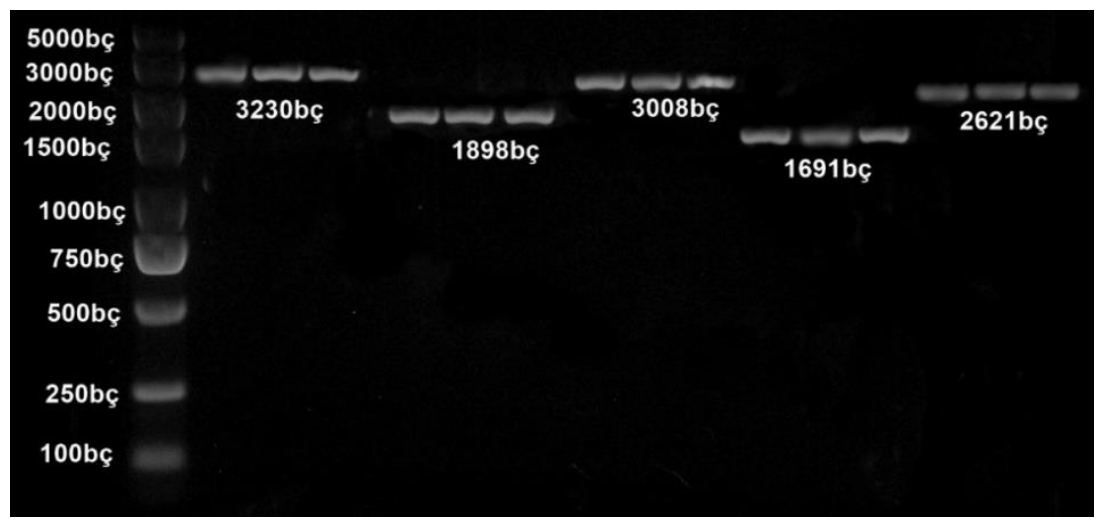

Şekil 2. Tüm genom kapsamında yapılan RT-PCR ürünlerinin agaroz jel elektroforezinde kontrol edilmesi sonucunda oluşan bant görüntüleri

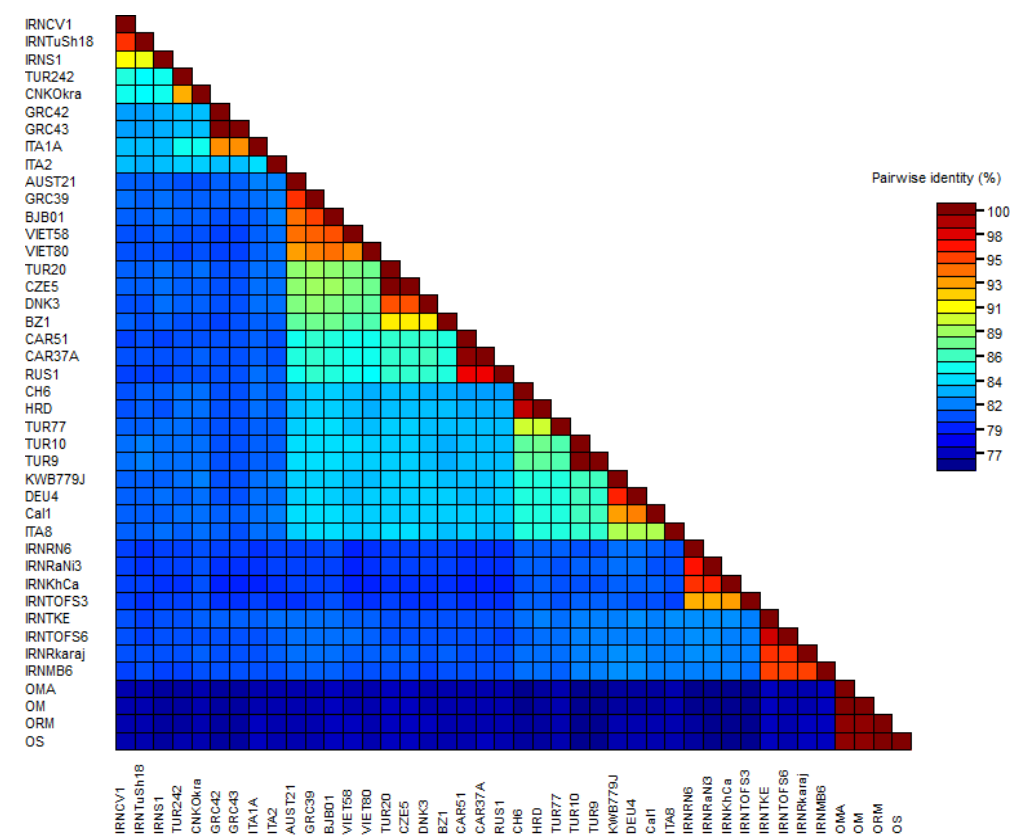

Şekil 3. Bamya turnip mosaic virus izolatlarının tüm genom nükleotit dizilimlerine göre diğer ülkelerdeki izolatlar ile gösterdiği benzerlik oranları

Amino asit düzeyinde tüm genom dizilimlerine göre CNKOkra izolatının gen bankasında bulunan diğer TuMV izolatları ile benzerlik oranları karşılaştırıldığında ise izolatların \%8698 arasında bir benzerlik gösterdiği tespit edilmiştir. CNKOkra izolat1 TUR242 isimli ve AP017815 erişim numaralı Türkiye izolatı ile \% 98 oranında benzerlik gösterirken, en düşük benzerliği ise \%86 oranında OMA, OM, ORM ve OS isimli AB701691, AB701690, AB701692 ve AB701693 erişim numaralı Almanya izolatları ile gösterdiği belirlenmiştir (Şekil 4).
Kozubek ve ark. (2007) yaptıkları bir çalışmada Cochlearia armoracia bitkisinden elde ettikleri 2 izolatın tüm genom dizilerini ortaya çıkararak bu dizilerin karşılaştırmalarını yapmışlardır. CAR37 ve CAR37A izolatlarının tüm genom karş1laştırmaları sonucunda $\% 86$ nükleotit ve $\% 94$ amino asit seviyesinde benzerlik gösterdiğini belirlemişlerdir. Wang ve ark. (2009), tarafindan Çin'de gerçekleştirilen başka bir çalışmada ise WFLB06 ve TANX2 TuMV izolatlarının tüm genom dizilerini belirleyerek karşılaştırmasını yapmışlardır. Tüm genom dizi 


\section{Ülkemiz Turnip Mosaic Virus Bamya İzolatının Tüm Genom Analizi}

karşılaştırmaları sonucunda izolatların \%90,98 nükleotit ve \%97,22 amino asit düzeyinde benzerlik gösterdiğini bildirmişlerdir.

Gerçekleştirilen bu çalışmalar kapsamında elde edilen bulgular ile bu çalışmada elde edilen bulgular birbiriyle paralellik göstermektedir.

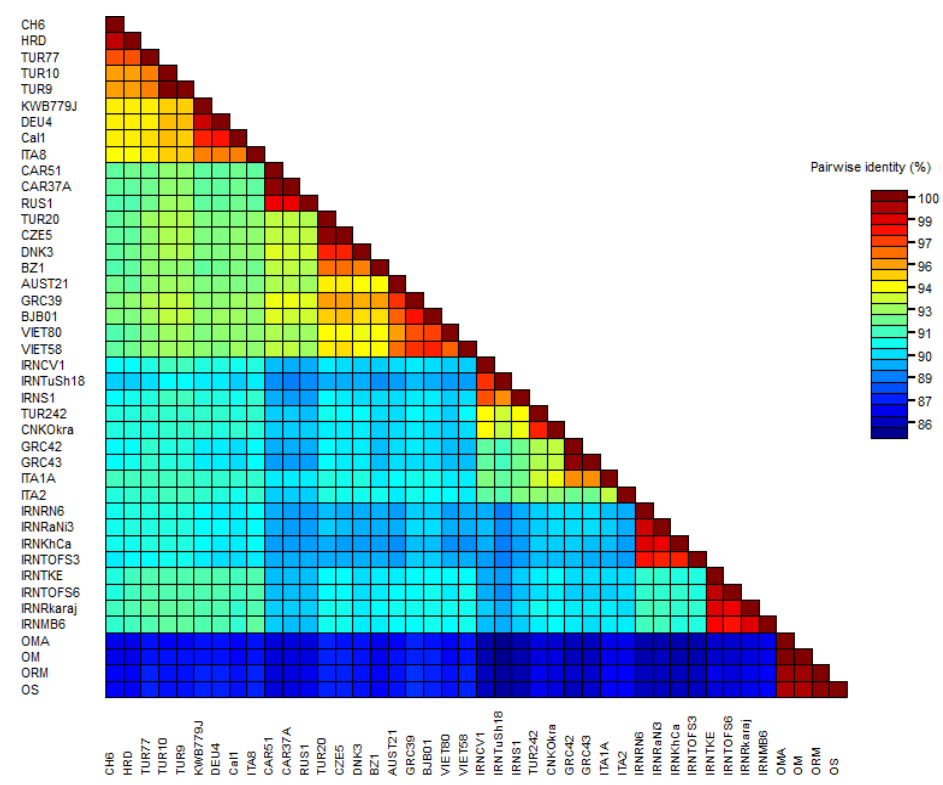

Şekil 4. Bamya turnip mosaic virus izolatlarının tüm genom amino asit dizilimlerine göre diğer ülkelerdeki izolatlar ile gösterdiği benzerlik oranları

Bamya TuMV izolatının farklı gen bölgelerine göre diğer ülkelerdeki izolatlar ile nükleotit ve amino asit düzeyindeki benzerlik oranları da incelendiğinde bamya Türk izolatının genel olarak diğer tüm izolatlar ile nükleotit düzeyinde en düşük \%72, en yüksek ise \%96 benzerlik gösterdiği görülmüştür. Amino asit düzeyinde ise en düşük \%76, en yüksek ise $\% 96$ benzerlik gösterdiği belirlenmiştir (Çizelge 3).

Bamya TuMV izolatının tüm genom düzeyinde filogenetik ilişkilerin belirlenmesi amacı ile nükleotit düzeyinde filogenetik analizleri gerçekleştirilmiştir. Filogenetik soy ağac1 literatüre paralel olarak 6 ana gruba ayrıldığ belirlenmiştir (Yasaka ve ark., 2017). Orchis grubunda 4 izolat, Iranian grubunda 8 izolat, Asian-BR grubunda 5 izolat, basal-BR grubunda 4 izolat, world-B grubunda 12 izolat, basal-B grubunda ise 9 izolat bulunmaktadır. Bamya TuMV izolatının da tüm genom nükleotit dizilimleri (Şekil 5) ve sahip olduğu gen bölgelerinin tamamına göre basal-B grubunda olduğu tespit edilmiştir. Ayrıca basal-B grubunda bulunan bamya izolatının bu gruptaki diğer TuMV izolatları ile de göstermiş oldukları benzerlik oranlarının diğer gruplara göre kısmen daha yüksek olması da filogenetik ağaçlardaki grupları doğrulamaktadır (Çizelge 2). 


\section{Ülkemiz Turnip Mosaic Virus Bamya İzolatının Tüm Genom Analizi}

Çizelge 3. Türk bamya turnip mosaic virus izolatının farklı gen bölgelerine göre diğer ülkelerdeki izolatlar ile nükleotit ve amino asit düzeyinde göstermiș olduğu benzerlik oranları

\begin{tabular}{|c|c|c|c|c|c|c|c|c|}
\hline \multirow{4}{*}{$\begin{array}{l}\text { Genom } \\
\text { Bölgesi }\end{array}$} & \multicolumn{8}{|c|}{ Benzerlik Oranı (\%) } \\
\hline & \multicolumn{4}{|c|}{ Tüm İzolatlara Göre } & \multicolumn{4}{|c|}{ basal-B Grubuna Göre } \\
\hline & \multicolumn{2}{|c|}{ Nükleotit } & \multicolumn{2}{|c|}{ Amino asit } & \multicolumn{2}{|c|}{ Nükleotit } & \multicolumn{2}{|c|}{ Amino asit } \\
\hline & Max. & Min. & Max. & Min. & Max. & Min. & Max. & Min. \\
\hline $\mathrm{P} 1$ & 91 & 72 & 91 & 67 & 91 & 76 & 91 & 76 \\
\hline HC-Pro & 94 & 77 & 98 & 91 & 94 & 82 & 98 & 96 \\
\hline P3 & 96 & 72 & 98 & 72 & 96 & 82 & 98 & 85 \\
\hline $6 \mathrm{~K} 1$ & 93 & 78 & 98 & 92 & 93 & 80 & 98 & 98 \\
\hline $\mathrm{CI}$ & 94 & 78 & 99 & 92 & 94 & 85 & 99 & 97 \\
\hline $6 \mathrm{~K} 2$ & 87 & 72 & 96 & 74 & 87 & 79 & 96 & 85 \\
\hline VPG & 95 & 76 & 98 & 83 & 95 & 82 & 98 & 92 \\
\hline NIa & 96 & 76 & 100 & 91 & 96 & 83 & 100 & 98 \\
\hline $\mathrm{NIb}$ & 89 & 78 & 98 & 91 & 89 & 83 & 98 & 95 \\
\hline $\mathrm{CP}$ & 95 & 83 & 98 & 90 & 95 & 90 & 98 & 92 \\
\hline
\end{tabular}

Farzadfar ve ark. (2009), İran'da yaptıkları çalışmada Rapistrum rugosum ve Sisymberium loeselii bitkilerinden elde ettikleri IRNTRa6 ve IRNSS5 izolatlarının genomik RNA'larının tam uzunluktaki dizilerini belirlemişlerdir. Elde ettikleri bu dizilerin filogenetik analizi sonucunda bu iki izoatın basal-B grubunda yer aldığını saptamışlardır. Kim ve ark. (2019) Kore'de gerçekleştirilen başka bir çalışmada da; KIH1 ve HJY1 Kore izolatlarının tam nükleotit dizilerine dayalı gerçekleştirilen filogenetik analizleri sonucunda izolatların genetik ilişkilerini belirlemişlerdir. KIH1 ve HJY1 izolatlarının ve NCBI'da bulunan 38 TuMV izolatları ile karşılaştırılması sonucunda Japonya ve İtalya izolatları ile basal-B grubuna dahil olduğunu belirtmişlerdir. Ülkemizde gerçekleştirilen bir çalışmada Korkmaz ve ark. (2008), biyolojik olarak farklı iki izolatın, TUR1 ve TUR9'un genomik RNA'larının tam uzunluktaki sekanslarını belirlemişlerdir. Elde ettikleri bu dizilerin filogenetik analizi sonucunda, TUR1 ve TUR9 izolatlarının sirasiyla world-B ve Asya-BR gruplarına dahil olduğunu tespit etmişlerdir. Bu sonuçlar ile de
TuMV izolatlarının konukçu ve coğrafik orijinden bağımsız olarak filogenetik gruplarının değişebildiği öne çıkmaktadır. Bu bağlamda elde edilen sonuçlar birbirini destekler niteliktedir.

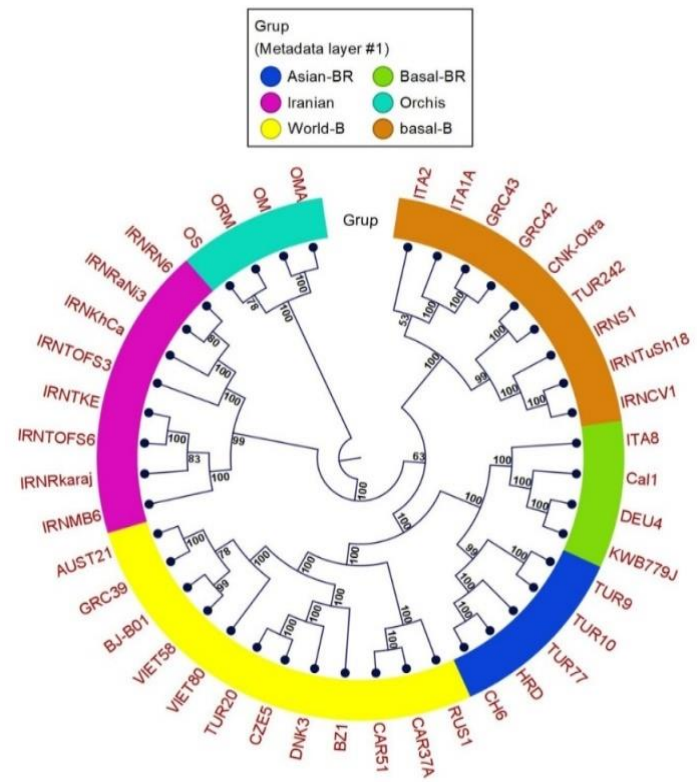

Şekil 5. Bamya turnip mosaic virus izolatının tüm genomunun nükleotit dizilimleri kullanılarak Neighbor joining (NJ) yöntemi ile oluşturulan filogenetik soy ağacı 


\section{Ülkemiz Turnip Mosaic Virus Bamya İzolatının Tüm Genom Analizi}

Gerçekleştirilen bu çalışma kapsamında dünyada ilk kez bamyayı enfekte eden TuMV izolatının tüm genom dizilimleri belirlenmiştir. Bundan sonra yapılacak olan çalışmalarda moleküler karakterizasyon çalışmalarının TuMV'nin diğer konukçularında da belirlenmesi ve dayanıklılık ile ilgili çalışmalara ağırlık verilmesi gerekmektedir.

\section{Teşekkür}

$\mathrm{Bu}$ çalışma birinci yazarın yüksek lisans tezinden üretilmiş olup, Çanakkale Onsekiz Mart Üniversitesi Bilimsel Araştırma Projeleri Koordinasyon Birimince Desteklenmiştir. Proje Numaras1: FYL-2019-3061.

\section{Kaynaklar}

Akbay, C., Candemir, S., Orhan, E. (2005) Türkiye'de yaş meyve ve sebze ürünleri üretim ve pazarlaması. Kahramanmaraş Sütçü Imam Üniversitesi Fen ve Mühendislik Dergisi 8 (2): 96-107.

Asare-Bediako, E., Van der Puije, G.C., Taah, K.J., Abole, E.A., Baidoo, A. (2014) Prevalence of okra mosaic and leaf curl diseases and Podagrica spp. damage of okra (Albelmoschus esculentus) plants. International Journal of Current Research and Academic Review 2 (6): 260-271.

Farzadfar, S., Tomitaka, Y., Ikematsu, M., Golnaraghi, A. R., Pourrahim, R., Ohshima, K. (2009) Molecular characterisation of turnip mosaic virus isolates from brassicaceae weeds. European Journal of Plant Pathology 124 (1): 45-55.

Gera, A., Lampel M., Cohen, J., Rosner, A. (2001) Okra (Hibiscus esculentus) - a new host of turnip mosaic virus in Israel. Plant Disease 85 (3): 336.

Gökdağ, S., Karanfil, A., Korkmaz, S. (2016) Çanakkale ili ispanak alanlarındaki şalgam mozaik virüsü ve hıyar mozaik virüsü varlığının belirlenmesi. Bahçe, özel sayı 2: 166-170.

Karanfil, A. (2020) Researching of usability of different total nucleic acid isolation methods in detection of potyvirus infections by RT-PCR. International Van Conference on Applied Sciences 43.

Karanfil, A., Korkmaz, S. (2019) Bamya bitkisinde şalgam mozaik virüsü (turnip mosaic virus)'nün tespiti ve moleküler karakterizasyonu. Bitki Koruma Bülteni 59 (3): 79-87.

Karanfil, A., Korkmaz, S. (2016) Çanakkale ili kanola (Brassica napus L.) üretim alanlarında şalgam mozaik virüsü (turnip mosaic virus; TuMV) enfeksiyonunun tanılanmasi ve karakterizasyonu. Bitki Koruma Bülteni 56 (2): 185-197.

Karanfil, A., Korkmaz, S. (2020) Çanakkale ve Tekirdağ illeri kanola üretim alanlarında önemli virüs hastalıklarının tanılanması ve karakterizasyonu. Ege Üniversitesi Ziraat Fakültesi Dergisi 57 (1): 53-62.

Kim, I. H., Ju, H.K., Gong, J., Han, J. Y., Seo, E.Y., Cho, S.W., Lim, H.S. (2019) A turnip mosaic virus determinant of systemic necrosis in Nicotiana benthamiana and a novel resistancebreaking determinant in Chinese cabbage identified from chimeric infectious clones. Phytopathology 109 (9): 1638-1647.

Korkmaz, S., Karanfil A. (2017) Detection of turnip mosaic virus from brassica plants by serological and molecular methods in Çanakkale, Turkey. 2nd International Balkan Agriculture Congress, 60.

Korkmaz, S, Tomitaka, Y., Onder, S., Ohshima, K. (2008) Occurrence and molecular characterization of Turkish isolates of Turnip mosaic virus. Plant Pathology 57 (6): 1155-1162.

Korkmaz, S., Cevik, B., Karanfil, A., Onder, S., Ohshima, K. (2020) Phylogenetic relationships and genetic structure of populations of turnip mosaic virus in Turkey. European Journal of Plant Pathology 156 (2): 559-569.

Kozubek, E., Irzykowski, W., Lehmann, P. (2007) Genetic and molecular variability of a turnip mosaic virus population from horseradish (Cochlearia armoracia L.). 


\section{Ülkemiz Turnip Mosaic Virus Bamya İzolatının Tüm Genom Analizi}

Journal of Applied Genetics 48 (3): 295306.

Lamont, W.J. (1999) Okra-A versatile vegetable crop. HortTechnology 9 (2): 179-184.

Li, R., Mock, R., Huang, Q., Abad, J., Hartung, J., Kinard, G. (2008) A reliable and in expensive method of nucleic acid extraction for the PCR-based detection of diverse plant pathogens. Journal of Virological Methods 154 (1-2): 48-55.

Muhire, B.M., Varsani, A., Martin, D.P. (2014) SDT: A virus classification tool based on pairwise sequence alignment and identity calculation. PLoS One, 9: 0108277.

Ohshima, K., Yamaguchi, Y., Hirota, R., Hamamoto, T., Tomimura, K., Tan, Z.Y., Sano, T., Azuhata, F., Walsh, J.A., Fletcher, J., Chen, J.S., Gera, A., Gibbs, A. (2002) Molecular evolution of turnip mosaic virus: evidence of host adaptation, genetic recombination and geographical spread, Journal of General Virology, 83 (6): 1511-21.

Provvidenti, R., Brunt, A.A., Crabtree, K., Dallwitz, M.J., Gibbs, A.J., Watson, L. (1996) Turnip mosaic potyvirus, Viruses of Plants, $\mathrm{CAB}$ International, Wallingford, UK.

Shevchenko, O., Yasaka, R., Tymchyshyn, O., Shevchenko, T., ve Ohshima, K. (2018) First evidence of the occurrence of Turnip mosaic virus in Ukraine and molecular characterization of its isolate. Journal of Phytopathology 166 (6): 429437.

Wang, H.Y., Liu, J.L., Gao, R., Chen, J., Shao, Y.H., Li, X.D. (2009) Complete genomic sequence analyses of Turnip mosaic virus basal-BR isolates from China. Virus Genes 38 (3): 421-428.

Yasaka, R., Fukagawa, H., Ikematsu, M., Soda, H., Korkmaz, S., Golnaraghi, A., Ohshima, K. (2017) The timescale of emergence and spread of turnip mosaic potyvirus. Scientific Reports 7 (1): 1-14.

Zheng, G.H., Peng, D.W., Tong, Q.X., Zheng, Z.Z., Ming, Y.L. (2017) Occurrence of turnip mosaic virus in Phalaenopsis sp. in China. Journal of Plant Pathology 99

(3): 703-706. 